Citation: A. Moukahel, S.G. Kumari, A.A. Hamed, M. Sharman, S. Ahmed (2021) Distribution and identification of luteovirids affecting chickpea in Sudan. Phytopathologia Mediterranea 60(2): 199-214. doi: 10.36253/phyto-12135

Accepted: March 25, 2021

Published: September 13, 2021

Copyright: ( ) 2021 A. Moukahel, S.G. Kumari, A.A. Hamed, M. Sharman, S. Ahmed. This is an open access, peerreviewed article published by Firenze University Press (http://www.fupress. $\mathrm{com} / \mathrm{pm}$ ) and distributed under the terms of the Creative Commons Attribution License, which permits unrestricted use, distribution, and reproduction in any medium, provided the original author and source are credited.

Data Availability Statement: All relevant data are within the paper and its Supporting Information files.

Competing Interests: The Author(s) declare(s) no conflict of interest.

Editor: Nihal Buzkan, Kahramanmaraş Sütçü Imam University, Turkey.

\section{Research Papers \\ Distribution and identification of luteovirids affecting chickpea in Sudan}

\author{
Abdulrahman MOUKAHEL ${ }^{1}$, SafaA G. KUMARI ${ }^{1, *}$, Abdelmagid Adlan \\ HAMED $^{2}$, MURRAY SHARMAN ${ }^{3}$, SEID AHMED ${ }^{4}$ \\ ${ }^{1}$ International Center for Agricultural Research in the Dry Areas (ICARDA), Terbol Sta- \\ tion, Beqa'a, Zahle, Lebanon \\ 2 Plant Pathology Research Program, Agricultural Research Corporation, Wad Medani, \\ Sudan \\ ${ }^{3}$ Department of Agriculture and Fisheries, Brisbane, Queensland, Australia. \\ ${ }^{4}$ International Center for Agricultural Research in the Dry Areas (ICARDA), Rabat, \\ Morocco \\ ${ }^{\star}$ Corresponding author. E-mail: s.kumari@cgiar.org
}

Summary. In Sudan yellowing viruses are key production constraints in pulse crops. Field surveys were carried out to identify luteovirids affecting chickpea crops in the major production regions (Gezira Scheme and River Nile State). A total of 415 chickpea plant samples with yellowing and stunting symptoms were collected during the 2013, 2015 and 2018 growing seasons. Serological results (Tissue-blot immunoassays) showed that Luteoviridae and Chickpea chlorotic dwarf virus (CpCDV, genus Mastrevirus, family Geminiviridae) were the most common viruses, with rare infections with Faba bean necrotic yellows virus (FBNYV, genus Nanovirus, family Nanoviridae). Some samples reacted only with a broad-spectrum luteovirid monoclonal antibody (5G4-MAb), and others showed cross reactions between the specific monoclonal antibodies, suggesting the occurrence of new luteovirid variants. Serological results were confirmed by amplification with reverse transcription-polymerase chain reaction (RTPCR) and sequencing of the partial coat protein gene. Molecular analyses provided a basic, sufficient and reliable characterization for four viruses affecting chickpea that belong to Polerovirus (family Luteoviridae). These were Cucurbit aphid-borne yellows virus (CABYV), Pepper vein yellows virus (PeVYV), Pepo aphid-borne yellows virus (PABYV) and Cotton leafroll dwarf virus (CLRDV), that shared high similarity with the type sequences. Phylogenetic analyses also revealed high similarity to luteovirid species. This study has established reliable, rapid and sensitive molecular tools for the detection of luteovirid species.

Keywords. Molecular characterization, sequence alignment, Polerovirus, Luteoviridae, Sudan.

\section{INTRODUCTION}

Chickpea (Cicer arietinum L.) is an economically important food crop in West Asia and North Africa (WANA) and in semi-arid areas of the world 
(Van der Maesen, 1987). The total world area under chickpea cultivation during the 2018 cropping season was 1.78 million ha with an estimated annual production of 17 million tonnes (FAO, 2018), making chickpea the third most important pulse crop after soybean and common bean. Chickpea is an important source of protein in human diets and plays a significant role in farming systems (Merga and Haji, 2019).

In Sudan, chickpea is the third most economically important food legume crop after faba bean and cowpea, as a cash crop that generates income for farmers and rural communities, and as a significant source of protein for Sudanese people (Mohamed et al., 2015). It is traditionally grown as a winter crop in River Nile State, northern Sudan. However, chickpea production has recently expanded to the central clay plain of central Sudan. The Gezira Scheme is one of the world's largest irrigation systems under one management, centred in the Sudanese state of Gezira, southeast of the confluence of the Blue Nile and White Nile at the city of Khartoum. The major crops in the Gezira Scheme are cotton, vegetable crops, cereals (sorghum and wheat), and currently kabuli type chickpea production is expanding due to its high price and low cost of production. The chickpea area harvested in Sudan during 2018 was 6,716 ha, and yielded 11,698 tonnes (FAO, 2018). The productivity in Sudan is generally low $\left(1.75 \mathrm{t} \mathrm{ha}^{-1}\right)$ (FAO, 2018), partly due to the use of inferior seeds purchased from local markets or imported from neighboring countries. Chickpea fields planted in November each year (early planting) are susceptible to high virus and wilt/root rot infections (Mohamed et al., 2015; 2018). Late planted crops (December/early January) showed low amounts of virus and root rot infections, but are more exposed to heat than early sown crops (Abdelmagid Adlan Hamed, personal communication), and this leads to high amounts of empty pods.

Generally, diseases causing yellowing, stunting and leaf roll symptoms are primarily caused by luteovirids, which are considered the most destructive virus diseases that infect cool season food legumes worldwide (Bos et al., 1988; Makkouk et al., 2003c; 2014; Kumar et al., 2008; Kumari et al., 2009). Virus species in the family Luteoviridae are transmitted in a circulative, non-propagative manner by specific aphid vectors. These viruses often cause phloem necroses that spread from inoculated sieve elements and cause symptoms by suppressing translocation, reducing plant growth and prompting chlorophyll loss, which results in characteristic yellowing and dwarfing of infected plants. Several members of the Luteoviridae have host ranges largely restricted to one plant family, and other members infect plants in several or many families. For instance, Bean leafroll virus (BLRV) and Soybean dwarf virus (SbDV) (Luteovirus) infect mainly legumes, whereas Beet western yellows virus (BWYV, Polerovirus) infects more than 150 species of plants in over 20 families (Domier, 2011).

Serologically, virus species in the Luteoviridae (mainly those in Polerovirus) cannot be distinguished using polyclonal antisera (Duffus and Russell, 1975; Govier, 1985) and most monoclonal antibodies (MAbs) (Oshima and Shikata, 1990; Smith et al., 1996), due to cross reactions with non-target species. Furthermore, antibodies for many species within this family are not easily available (D'Arcy et al., 1989; Fortass et al., 1996). Molecular assays are generally more sensitive than serological tests, especially with luteovirids, which are present in lower concentrations than many other plant viruses. Reverse transcription-polymerase chain reaction (RT-PCR) technology provides more sensitive assays which have the potential to identify luteovirid-infected plants more reliably, especially in the early stages of infection, and also helps to improve virus classifications (Lemaire et al., 1995; Hauser et al., 2000; Xiang et al., 2008a, 2008b; Mnari-Hattab et al., 2009; Shang et al., 2009; Knierim et al., 2010). For example, virus isolates previously identified as BWYV have been reclassified as four distinct virus species (BWYV, Beet chlorosis virus (BChV), Beet mild yellowing virus (BMYV), and Turnip yellows virus (TuYV)) on the basis of differences in host range and molecular characterizations (Hauser et al., 2000; 2002; D'Arcy and Domier, 2005). Using molecular techniques, Chickpea chlorotic stunt virus (CpCSV), identified as a new member of Polerovirus, has been shown to naturally infect a range of cool-season food legumes, and cause leaf yellowing and plant stunting in Ethiopia and Syria (Abraham et al., 2006) and in many countries in WANA region (Kumari et al., 2007; Asaad et al., 2009). In addition, many virus isolates that were identified as a luteovirid based on their positive reactions with a broad spectrum MAb "5G4" (Katul, 1992) in the past, did not react serologically with the available specific MAbs (Makkouk et al., 1988; Abraham et al., 2008; Mustafayev et al., 2011; Kumari et al., 2017). These viruses remained unidentified due to the lack of specific antibodies or appropriate molecular tools.

Chickpea can be naturally infected with a number of viruses causing yellowing and stunting symptoms (Nene et al., 1996; Kumar et al., 2008). However, in Sudan, four viruses have been identified to naturally this host and cause significant economic damage. These are, Faba bean necrotic yellows virus (FBNYV, Nanovirus, Nanoviridae), Chickpea chlorotic dwarf virus (CpCDV, Mastrevirus, Geminiviridae), CpCSV and BWYV (Abra- 
ham et al., 2009; Makkouk et al., 2003b; 1995; Makkouk, 2020). Cucurbit aphid-borne yellows virus (CABYV) has also been reported by Kumari et al. (2018) to infect chickpea in Sudan and cause stunting, yellowing and necrosis. However, that study suggested the presence of other luteovirids in survey samples, but the identity of these was not reported.

Previous studies and surveys conducted in many regions of Sudan have indicated the occurrence of unrecognized viruses with wide distributions and sometimes with high incidence. However, the diversity of luteovirid species infecting cool-season food legume crops in Sudan has not been previously and extensively studied, and information on the incidence of specific viruses affecting these crops is limited. To address this knowledge gap, we carried out field surveys in the main chickpea production areas of Sudan to accurately characterize the identity, diversity, variability and geographic distributions of luteovirid species that affect chickpea, using conventional and molecular analyses.

\section{MATERIALS AND METHODS}

\section{Field surveys and serological tests}

Field surveys were conducted in the major chickpea production areas in Sudan, including areas of the Gezira Scheme (middle, north and south) and River Nile State (Hudeiba Agriculture Research Station, Berber and Shendi). The 204 chickpea samples collected by Kumari et al. (2018) in February 2013 and March 2015 were included in the present study, to investigate luteovirid diversity in addition to the CABYV already reported. A further 211 chickpea samples were collected in February 2018 when the crops were at the flowering/pod setting stage. Shoot samples from a total of 415 chickpea plants with yellowing and stunting symptoms were collected from 35 fields (133 plants from ten fields in 2013; 71 plants from four fields in 2015 and 211 plants from 21 fields in 2018). In each field visited, data on field location, crop condition, growth stage, virus disease symptoms, virus disease incidence and aphid populations were recorded. Virus disease incidence in each field was determined on the basis of visual virus symptoms and the number of infected plants per $\mathrm{m}^{2}$ at randomly chosen locations in the field, and were grouped into five categories $(<1 \%, 1-5 \%, 6-20 \%, 21-50 \%$ or $>50 \%)$. The fresh stem of each sample plant was blotted on nitrocellulose membrane (NCM, $0.45 \mu \mathrm{m}$, Bio-Rad, Cat No. 1620115) in ten replicates. The leaves of all collected samples were dried over silica gel or lyophilized for further molecular analyses.
Three replicates of blotted NCMs were tested for the presence of viruses by tissue-blot immunoassay (TBIA; Makkouk and Kumari, 1996), using a broad-spectrum legume luteovirid monoclonal antibody (MAb) (5G4; Katul, 1992), MAb for FBNYV (3-2E9; Franz et al., 1996) and a polyclonal antibody for CpCDV (Kumari et al., 2006).

To identify individual luteovirids, samples that reacted positively with MAb 5G4 in TBIA (23 samples in 2013, 18 samples in 2015, 45 samples in 2018) were retested further, using specific MAbs to BWYV (A5977 from Agdia, USA), BLRV (4B10; Katul, 1992), SbDV (ATCC PVAS-650, USA) and a mixture of three MAbs (1-1G5, 1-3H4 and 1-4B12) produced against an Ethiopian isolate of CpCSV (CpCSV-Eth) and a mixture of three MAbs (5-2B8, 5-3D5 and 5-5B8) produced against a Syrian isolate of CpCSV (CpCSV-Sy) (Abraham et al., 2006, 2009).

\section{Molecular analyses}

RNA extraction

Total RNA was extracted from 50 to $100 \mathrm{mg}$ of virus-infected lyophilized tissue following a user-developed protocol using McKenzie lysis buffer (McKenzie et al., 1997) with the RNeasy ${ }^{\oplus}$ Plant Mini Kit (Cat No. 74904, Qiagen). RNAs for all tested samples were stored as solutions in Nuclease free-water at $-80^{\circ} \mathrm{C}$.

\section{Complementary DNA (cDNA)}

Synthesis of cDNA was achieved using the M-MLV Reverse Transcriptase kit (Cat No. 28025013, Invitrogen) as per the manufacturer's instructions, with reverse primer AS3 (Abraham et al., 2008) (Table 1). Three $\mu \mathrm{L}$ of total RNA, $1 \mu \mathrm{L}$ of $10 \mu \mathrm{M}$ AS3 primer, $1 \mu \mathrm{L}$ of Nuclease free water and $1 \mu \mathrm{L}$ of $10 \mu \mathrm{M}$ dNTPs (2'-deoxynucleotide $5^{\prime}$-triphosphates) were heated at $65^{\circ} \mathrm{C}$ for $5 \mathrm{~min}$. The reaction was cooled on ice for $2 \mathrm{~min}$ and the following reagents were added: $2 \mu \mathrm{L} 5 \times$ First-Strand Buffer, $1 \mu \mathrm{L}$ $0.1 \mathrm{M}$ DTT and $0.5 \mu \mathrm{L}$ Nuclease free water. The reaction was incubated at $37^{\circ} \mathrm{C}$ for $2 \mathrm{~min}$ then $0.5 \mu \mathrm{L}$ of $\mathrm{M}-\mathrm{MLV}$ RT enzyme was added (final volume $10 \mu \mathrm{L}$ ) followed by a further $50 \mathrm{~min}$ at $37^{\circ} \mathrm{C}$ before deactivating at $70^{\circ} \mathrm{C}$ for $15 \mathrm{~min}$.

Reverse transcription-polymerase chain reaction (RT-PCR)

The success of reverse transcription was checked by performing a PCR using the generic primer pairs (AS3/ Pol3870F) (Sharman et al., 2015) to amplify 370 bp of 
Table 1. Luteovirid primer sets used in this study.

\begin{tabular}{|c|c|c|c|c|}
\hline Primer pairs & Primer Sequence ( $5^{\prime}$ to $\left.3^{\prime}\right)$ & $\begin{array}{l}\text { Product } \\
\text { Size (bp) }\end{array}$ & Target virus species ${ }^{\mathrm{a}}$ & Reference \\
\hline \multicolumn{5}{|l|}{ Generic primers } \\
\hline AS3 & CACGCGTCIACCTATTTIGGRTTITG & 370 & $\begin{array}{c}\text { CLRDV, CpCSV, CABYV, PLRV, BWYV, } \\
\text { TuYV, BLRV, CBTV, SbDV }\end{array}$ & Abraham et al., 2008 \\
\hline Pol3870F & ATCACBTTCGGGCCGWSTYTWTCAGA & & & Sharman et al., 2015 \\
\hline \multicolumn{5}{|c|}{ Specific Multiplex primers } \\
\hline \multicolumn{5}{|c|}{ Master Mix-I } \\
\hline \multicolumn{5}{|l|}{ AS3 } \\
\hline BLRV3589F & CAAGGAGACGTTTACCAGTCGT & 551 & BLRV & Sharman, unpublished data \\
\hline BWYV3969F & GTCTCCGARGCCTCTTCCCAA & 276 & BWYV/TuYV & Sharman, unpublished data \\
\hline SbDV3731F & CGWGTTTTCRAAGGACGGCA & 418 & SbDV & Sharman, unpublished data \\
\hline PBMYV3396F & GGTTGGTTCTTCCAGTCCAAT & 838 & PBMYV & Sharman et al., 2021 \\
\hline \multicolumn{5}{|l|}{ Master Mix-II } \\
\hline \multicolumn{5}{|l|}{ AS3 } \\
\hline CABYV3635F & GAAACCGCCGACGCCCTAAT & 474 & CABYV & Sharman, unpublished data \\
\hline CpCSV3705F & AAYARGCGYMCTGTTCAGCGGGC & 566 & CpCSV & Sharman, unpublished data \\
\hline \multicolumn{5}{|c|}{ Specific Uniplex primer pairs } \\
\hline Pol3982R & CGAGGCCTCGGAGATGAACT & 310 & CLRDV & Sharman et al., 2015 \\
\hline CLRDV3675F & CCACGTAGRCGCAACAGGCGT & & & \\
\hline PeR & TCGCTTGCCCGCCTTTGGTG & 1249 & PeVYV & Zhang et al., 2015 \\
\hline $\mathrm{PeF}$ & GGAGCGTTGCGGAATGGATGC & & & \\
\hline
\end{tabular}

a Virus acronyms are CLRDV = Cotton leafroll dwarf virus; CpCSV = Chickpea chlorotic stunt virus; CABYV = Cucurbit aphid-borne yellows virus; PLRV = Potato leafroll virus; BWYV = Beet western yellows virus; TuYV = Turnip yellows virus; BLRV = Bean leafroll virus; CBTV = Cotton bunchy top virus; SbDV = Soybean dwarf virus; PhBMYV = Phasey bean mild yellows virus; PeVYV = Pepper vein yellows virus.

the partial coat protein $(C P)$ gene (Table 1), using the My Taq polymerase kit (Cat No. BIO-21108, Bioline). The positive samples with sharp band were processed by Multiplex RT-PCR (MP-PCR) (Murray Sharman, unpublished data), using the generic reverse primer AS3 with species-specific primers for Phasey bean mild yellows virus (PBMYV), CpCSV, BWYV, SbDV, BLRV and CABYV (Table 1), and by following the manufacturer's instructions for the My Taq polymerase kit (final volume $10 \mu \mathrm{L})$. Due to the proximity in product sizes for some primers, the MP-PCR amplification mixture was divided in two multiplex master mixes; master mix-I included AS3 with primers BLRV3589F, BWYV3969F, SbDV3731F and PhBMYV3396F and master mix-II consisted of AS3 with CABYV3635F and CpCSV3705F (Table 1). These primers amplify partial $C P$ gene. Positive controls for all tested viruses were used in both master mixes as checks to accurately identify PCR products of the different viruses. The PCR for both sets consisted of an initial denaturation of $95^{\circ} \mathrm{C}$ for $1 \mathrm{~min}$, then 35 cycles $\left(95^{\circ} \mathrm{C}\right.$ for $30 \mathrm{sec}, 62^{\circ} \mathrm{C}$ for $20 \mathrm{sec}, 56^{\circ} \mathrm{C}$ for $10 \mathrm{sec}, 72^{\circ} \mathrm{C}$ for $30 \mathrm{sec}$ ) followed by a final extension of $72^{\circ} \mathrm{C}$ for $3 \mathrm{~min}$. All PCR products were analyzed on $1.5 \%$ agarose gel stained with
RedSafe $^{\mathrm{TM}}$ Nucleic Acid Staining Solution (20,000×) (Cat No. 21141, iNtRON) with final concentration of $5 \%$ in $0.5 \%$ TBE (Tris-borate-EDTA) buffer.

In addition to the above primers, two specific uniplex primer pairs targeted Pepper vein yellows virus (PeVYV) (PeF/PeR; Zhang et al., 2015) and Cotton leafroll dwarf virus (CLRDV) (CLRDV3675F/Pol3982R; Sharman et al., 2015) (Table 1) to confirm the sequencing outputs of the DNA fragments generated by AS3/ Pol3870F.

DNA sequencing and molecular analysis

PCR amplicons of interest were amplified with total volumes of $50 \mu \mathrm{L}$. From each of these, $5 \mu \mathrm{L}$ was analyzed on agarose gel, and the high-quality products were directly sequenced by the Sanger method following the instructions of a commercial sequencing company (Macrogen). The sequences were compared with available sequences in the GenBank database using the basic local alignment search tool (BLAST; Altschul et al., 1997; 2005). In this study, BLAST search and sequence 
analyses were carried out based on the greatest similarity of the submitted sequences with the following four GenBank accessions: GenBank accession Nos. KC685313 for PeVYV, KJ789902 for Pepo aphid-borne yellows virus (PABYV), EU871539 for CLRDV and EX398665 for CABYV. Sequences of 24 Sudanese isolates were submitted to the GenBank (see Table 4 for accession numbers).

Sequence assembly and pairwise comparisons were carried out using MEGA-X (Kumar et al., 2018) for the partial CP sequence of 18 Polerovirus isolates (from 13 countries) from the GenBank database and four Sudanese chickpea isolates representing four polerovirus species identified further in the present study (SuCp122-13: CABYV, SuCp31-15: CLRDV, SuCp29-15: PABYV and SuCp42-13: PeVYV). Sequence alignments were generated under the Hasegawa-Kishino-Yano (HKY) (Hasegawa et al., 1985) model with a bootstrap value of 1000 by MEGA-X. Nucleotide pairwise similarities were calculated using SDTv 1.2 (Muhire et al., 2014).

Phylogenetic analyses of nucleotide and amino acid sequences were carried out using a Clustal_X program after multiple alignment of sequences by neighbour joining algorithms with 500 bootstrap replications (Thompson et al., 1997).

\section{RESULTS}

\section{Field distribution and serological tests}

The most commonly observed symptoms suggestive of virus infection in chickpea fields were yellowing, stunting, chlorosis and reddening of the leaves and tip wilting (Figure 1). Based on the symptoms observed in the fields, $17 \%$ of chickpea fields (one field in 2013 and five fields in 2018) had virus incidence of $5 \%$ or less, $31 \%$ of fields had incidence of 6-20\% (two fields in 2013 and nine in 2018), $29 \%$ of fields had incidence of $21-50 \%$ (four fields in 2013, two in 2015 and four in 2018), and 8 fields (23\%) had virus incidence greater than 50\% (three fields in 2013, two in 2015 and three in 2018).

TBIA results from 415 symptomatic plant samples collected during the 2013, 2015 and 2018 growing seasons indicated that $\mathrm{CpCDV}$ was the most common virus, with average relative infection rates of $59 \%$ of the tested samples in 2013, 89\% in 2015, and $17 \%$ in 2018. In addition, $21 \%$ of tested samples reacted positively with a broad-spectrum legume luteovirid MAb (5G4) (23 samples in 2013, 18 in 2015 and 45 in 2018), whereas FBNYV infection was detected in only one sample during 2013 (Table 2). When 86 samples that reacted positively with $5 \mathrm{G} 4 \mathrm{MAb}$ were further tested using specific luteovirid MAbs, 11 samples reacted with BWYV MAb, 22 samples reacted with CpCSV MAbs, 23 samples reacted with both BWYV and CpCSV MAbs, and the 30 remaining samples reacted only with 5G4 MAb (Table 3).

\section{Molecular analyses}

According to TBIA reactions with different MAbs, 36 samples were selected for further molecular characterization (eight samples that reacted only with MAb $5 \mathrm{G} 4$, seven that reacted positively with 5G4, BWYV and CpCSV MAbs, and 21 samples that reacted positively with 5G4 samples and CpCSV MAbs). The generic primer pair AS3/Pol3870F amplified the expected product size of $370 \mathrm{bp}$ from 33 chickpea samples out of 36 samples tested (Figure 2-A). The MP-PCRs (set 1 and set 2) results showed presence of CABYV in 12 samples with amplicon size of approx. 474 bp (Figure 2-B). However, there were 21 samples that were positive in generic RTPCR AS3/Pol3870F but were negative in all MP-PCRs. Thus, all unrecognized samples along with five samples that were amplified with CABYV-specific primer pairs were sequenced by Sanger sequencing.

The sequence analyses confirmed presence of CABYV (five samples) with $96 \%$ nt similarity with the



Figure 1. Plants showing yellowing and stunting symptoms in chickpea fields in the Gezira Scheme, Sudan during the 2015 cropping season. 
Table 2. Results of serological tests (Tissue blot immunoassay, TBIA) for chickpea samples collected from different regions of Sudan during the 2013, 2015 or 2018 growing seasons.

\begin{tabular}{|c|c|c|}
\hline \multirow{2}{*}{ Year/Region } & \multirow{2}{*}{$\begin{array}{cc}\begin{array}{c}\text { Number } \\
\text { of fields }\end{array} & \begin{array}{c}\text { of } \\
\text { visited }\end{array} \\
& \text { samples } \\
\text { tested }\end{array}$} & $\begin{array}{l}\text { Number of samples } \\
\text { reacted positively with }\end{array}$ \\
\hline & & $\begin{array}{c}\text { 5G4 FBNYV CpCDV } \\
(\mathrm{MAb})(\mathrm{MAb}) \quad(\mathrm{PAb})\end{array}$ \\
\hline
\end{tabular}

2013

Gezira Scheme

$\begin{array}{llllll}\text { North } & 5 & 68 & 6 & 0 & 63\end{array}$

$\begin{array}{llllll}\text { Middle } & 3 & 32 & 3 & 1 & 14\end{array}$

$\underline{\text { River Nile State }}$

$\begin{array}{llllll}\text { Hudeiba Agr. Res. station } & 1 & 25 & 14 & 0 & 1\end{array}$

\begin{tabular}{llllll} 
Berber & 1 & 8 & 0 & 0 & 1 \\
\hline
\end{tabular}

2015

Gezira Scheme

\begin{tabular}{llllll}
\hline South & 4 & 71 & 18 & 0 & 63
\end{tabular}

2018

Gezira Scheme

North Gezira

Middle Gezira

$\begin{array}{lllll}7 & 58 & 11 & 0 & 2\end{array}$

River Nile State

\begin{tabular}{lccccc} 
Shendi & 2 & 19 & 7 & 0 & 10 \\
Hudeiba Agr. Res. station & 1 & 21 & 0 & 0 & 0 \\
Berber & 2 & 32 & 4 & 0 & 4 \\
\hline Total & 34 & 415 & 86 & 1 & 179 \\
\hline
\end{tabular}

a $5 \mathrm{G} 4$ (MAb): broad-spectrum legume luteovirid monoclonal antibody (Katul, 1992); FBNYV (MAb): Faba bean necrotic yellows virus (monoclonal antibody) (3-2E9; Franz et al., 1996); CpCDV (PAb): Chickpea chlorotic dwarf virus (Polyclonal antibody) (Kumari et al., 2006).

type reference sequence for CABYV (GenBank accession no. NC_003688), and three luteovirid species were detected for the first time from chickpea in Sudan (all belonging to Polerovirus), PeVYV (six samples), PABYV (14 samples) and CLRDV (one sample). Sequences were submitted to the GenBank, and the GenBank accession numbers are shown in Table 4.

When six PeVYV samples and one CLRDV sample were subjected to RT-PCR using specific primer pairs for PeVYV (PeF/PeR; Zhang et al., 2015) and CLRDV (CLRDV3675F/Pol3982R; Sharman et al., 2015) (Table 1), amplicons of the expected sizes (1249 bp for PeVYV and 310 bp for CLRDV) were generated (Figure 2-C and 2-D).

The comparison of detection methods between TBIA and MP-PCR clearly showed that there was greater variation in species detected than indicated by TBIA alone, i.e., the common character between the analyzed samples is that all these samples reacted positively with 5G4 MAb, which means there is no false positive reaction or cross reaction with another family of plant viruses. On the other hand, there was no compatibility between the serological results and molecular characterization. It is obvious that CpCSV and/or BWYV were not detected in any of the samples, despite that most samples reacted with CPCSV MAb mixtures and BWYV $\mathrm{MAb}$ due to the serological cross reaction which is common for luteovirids (Oshima and Shikata, 1990; Smith et al., 1996) (Table 4)

Pairwise comparisons of $\mathrm{CP}$ amino acid sequences of representative isolate for each virus indicated that the virus isolates from Sudan were probably members of recognized Luteoviridae species. The nucleotide sequence of the isolate SuCp42-13 showed that it was indistinguishable from PeVYV-Sudan isolate, despite that PeVYV-Sudan was isolated from hot pepper (Table 5). The phylogenetic analysis tree also showed that this isolate was close to PeVYV-Sudan (GenBank acces-

Table 3. Serological results of Tissue blot immunoassay (TBIA) with specific luteovirid monoclonal antibodies (MAbs) for chickpea samples collected from different regions of Sudan during the 2013, 2015 or 2018 growing seasons.

\begin{tabular}{|c|c|c|c|c|c|c|c|}
\hline \multirow{2}{*}{ Year } & \multirow{2}{*}{$\begin{array}{c}\text { Number of } \\
\text { samples reacted } \\
\text { with } 5 \mathrm{G} 4 \mathrm{MAb}^{\mathrm{a}}\end{array}$} & \multicolumn{5}{|c|}{ Number of samples reacted positively with MAbs ${ }^{\mathrm{b}}$} & \multirow{2}{*}{$\begin{array}{l}\text { Unidentified } \\
\text { luteovirids }\end{array}$} \\
\hline & & BWYV & CpCSV & BLRV & SbDV & CpCSV\& BWYV & \\
\hline 2013 & 23 & 4 & 6 & 0 & 0 & 9 & 4 \\
\hline 2015 & 18 & 0 & 1 & 0 & 0 & 7 & 10 \\
\hline 2018 & 45 & 7 & 15 & 0 & 0 & 7 & 16 \\
\hline Total & 86 & 11 & 22 & 0 & 0 & 23 & 30 \\
\hline
\end{tabular}

a 5G: broad-spectrum legume luteovirid monoclonal antibody (Katul, 1992).

${ }^{\mathrm{b}}$ Monoclonal antibodies used are BWYV: Beet western yellows virus (A5977 from Agdia, USA); BLRV: Bean leafroll virus (4B10; Katul, 1992); SbDV: Soybean dwarf virus (ATCC PVAS-650, USA); CpCSV: a mixture of three MAbs (1-1G5, 1-3H4 and 1-4B12) produced against an Ethiopian isolate of Chickpea chlorotic stunt virus (CpCSV-Eth), and a mixture of three MAbs (5-2B8, 5-3D5 and 5-5B8) produced against a Syrian isolate of CpCSV (CpCSV-Sy) (Abraham et al., 2006, 2009) 



Figure 2. (A) Detection of Cucurbit aphid-borne yellows virus (CABYV), Pepo aphid-borne yellows virus (PABYV), Pepper vein yellows virus (PeVYV) and Cotton leafroll dwarf virus (CLDRV) by RT-PCR using AS3/Pol3870F generic primers; (B) Detection of CABYV by MP-PCR using AS3/CABYV3635F specific primers; (C) Detection of CLRDV by RT-PCR using Pol3982R/CLRDV3675F specific primers (one sample from Sudan and four samples from Uzbekistan were used as positive controls); (D) Detection of PeVYV by RT-PCR using PeF/ PeR specific primers. M = DNA Ladder VC 100 bp Plus (Cat No. NL1405, vivantis, Malaysia).

sion no. KC685313) (Figure 3). BLAST analysis of the PCR product generated by AS3/Pol3870F revealed high nucleotide sequence similarity with Polerovirus viruses: 95-96\% similarity was found with PeVYV (accession no. KC685313) and 93-94\% for PABYV (accession no. KJ789902). Similarities of $90 \%$ were found for CLRDV (accession no. EU871539) and 90-92\% for CABYV (accession no. KX398665) (Table 4). A nucleotide sequence obtained from the isolate SuCp29-15 was also distinct from all other luteovirid sequences. Pairwise comparisons of the predicted CP amino acid sequences showed that isolate SuCp29-15 was close to the PABYVCote d'Ivoire isolate (GenBank accession no. KR476816) with 97\% similarity (Table 5; Figure 3).

The CP sequence of SuCp31-15 was $96 \%$ similar to that of the CLRDV-Brazil isolate, which was the closest phylogenetically. Similarly, isolate SuCp122-13 shared distinct similarity with both CABYV isolates from Tuni- sia (GenBank accession no. EF187345) and Italy (GenBank accession no. EF029113 (Table 5; Figure 3).

The phylogenetic comparison of the nucleotide sequence of the virus isolates grouped the isolates in distinct clusters depending on identical and different sequences which revealed that the grouping model is typically correlated to the geographical origin of the isolates (Figure 3). This result also was supported by a two-dimensional color-coded matrix of pairwise identity scores (Figure 4) generated by species demarcation tool (SDT) (Muhire et al., 2014), which revealed that the representative isolates have overlapping identity range with CP gene from GenBank isolates (59-99\%). Despite the fact that some virus isolates were identified from different hosts, the SDT showed similar identity as for isolate SuCp42-13 and reference isolate (PeVYV, GeneBank accession no. KC685313). 
Table 4. Designations, geographic origins, comparison and identity with reference GenBank accessions of chickpea luteovirids characterized in this study.

\begin{tabular}{|c|c|c|c|c|c|}
\hline Isolate name ${ }^{a}$ & $\begin{array}{c}\text { GenBank } \\
\text { accession } \\
\text { number }\end{array}$ & Region in Sudan & $\begin{array}{l}\text { TBIA reaction with } \\
\text { MAbs }{ }^{\mathrm{b}}\end{array}$ & $\begin{array}{c}\text { Virus sequence } \\
\text { Blastn_Reference } \\
\text { GenBank accessions }^{\mathrm{d}}\end{array}$ & Blastn similarity \% \\
\hline SuCp10-13 & MK461113 & North of Gezira Scheme & 5G4, CpCSV & PeVYV_KC685313 & 96 \\
\hline SuCp14-13 & MK461114 & North of Gezira Scheme & $5 \mathrm{G} 4$ & PeVYV_KC685313 & 96 \\
\hline SuCp42-13 & MK461115 & Middle of Gezira Scheme & 5G4, CpCSV & PeVYV_KC685313 & 95 \\
\hline SuCp108-13 & MK461116 & Hudeiba Agr. Res. Station, River Nile & 5G4, CpCSV & PeVYV_KC685313 & 96 \\
\hline SuCp111-13 & MK461120 & Hudeiba Agr. Res. Station, River Nile & $5 \mathrm{G} 4$ & PABYV_KJ789902 & 93 \\
\hline SuCp21-15 & MK461121 & South of Gezira Scheme & 5G4, CpCSV, BWYV & PABYV_KJ789902 & 94 \\
\hline SuCp22-15 & MK461122 & South of Gezira Scheme & 5G4, CpCSV & PABYV_KJ789902 & 94 \\
\hline SuCp26-15 & MK461123 & South of Gezira Scheme & $5 \mathrm{G} 4$ & PABYV_KJ789902 & 94 \\
\hline SuCp28-15 & MK461124 & South of Gezira Scheme & 5G4, CpCSV & PABYV_KJ789902 & 94 \\
\hline SuCp29-15 & MK461125 & South of Gezira Scheme & 5G4, CpCSV, BWYV & PABYV_KJ789902 & 94 \\
\hline SuCp30-15 & MK461126 & South of Gezira Scheme & 5G4, CpCSV & PABYV_KJ789902 & 94 \\
\hline SuCp32-15 & MK461127 & South of Gezira Scheme & 5G4, CpCSV & PABYV_KJ789902 & 94 \\
\hline SuCp33-15 & MK461128 & South of Gezira Scheme & 5G4, CpCSV & PABYV_KJ789902 & 94 \\
\hline SuCp34-15 & MK461129 & South of Gezira Scheme & 5G4, CpCSV, BWYV & PABYV_KJ789902 & 94 \\
\hline SuCp35-15 & MK461130 & South of Gezira Scheme & 5G4, CpCSV & PABYV_KJ789902 & 94 \\
\hline SuCp36-15 & MK461131 & South of Gezira Scheme & 5G4, CpCSV, BWYV & PABYV_KJ789902 & 94 \\
\hline SuCp37-15 & MK461132 & South of Gezira Scheme & 5G4, CpCSV & PABYV_KJ789902 & 94 \\
\hline SuCp38-15 & MK461133 & South of Gezira Scheme & 5G4, CpCSV & PABYV_KJ789902 & 94 \\
\hline SuCp31-15 & MK411565 & South of Gezira Scheme & 5G4, CpCSV & CLRDV_EU871539 & 90 \\
\hline SuCp106-13 e & MG933685 & Hudeiba Agr. Res. Station, River Nile & 5G4, CpCSV & CABYV_KX398665 & 91 \\
\hline SuCp110-13 & MK461117 & Hudeiba Agr. Res. Station, River Nile & 5G4, CpCSV & CABYV_KX398665 & 91 \\
\hline SuCp117-13 & MK461118 & Hudeiba Agr. Res. Station, River Nile & $5 \mathrm{G} 4$ & CABYV_KX398665 & 90 \\
\hline SuCp122-13 e & MG933686 & Hudeiba Agr. Res. Station, River Nile & 5G4, CpCSV & CABYV_KX398665 & 90 \\
\hline SuCp23-15 & MK461119 & South of Gezira Scheme & 5G4, CpCSV, BWYV & CABYV_KX398665 & 92 \\
\hline
\end{tabular}

a The last two numbers refer to year of collection.

${ }^{\mathrm{b}}$ Information of MAbs are given in Table 3. Virus acronym used is CpCSV: Chickpea chlorotic stunt virus; BWYV: Beet western yellows virus. ${ }^{c}$ All samples were amplified only with generic primer pairs (AS3/Pol3870F) except last 5 samples were amplified with AS3/CABYV3635F in addition to generic primer pairs.

d Virus acronym used is CLRDV: Cotton leafroll dwarf virus; CABYV: Cucurbit aphid-borne yellows virus; PeVYV: Pepper vein yellows virus; PABYV: Pepo aphid-borne yellows virus.

${ }^{\mathrm{e}}$ CABYV isolates reported in Kumari et al. (2018).

\section{DISCUSSION}

The present study has shown that CpCDV and luteovirids were the most common viruses affecting chickpea crops in Sudan, whereas FBNYV was rare. These viruses have been reported on faba bean and chickpea in many countries in the WANA region (Kumar et al., 2008; Kumari and Makkouk, 2007; Makkouk and Kumari, 2009). CpCDV has been reported on faba bean and chickpea (Makkouk et al., 1995), and FBNYV (Makkouk et al., 2003b) and BLRV (Makkouk et al., 1988) were reported on faba bean in Sudan, based on serological assays using polyclonal antibodies.

Based on serological results, 11 samples reacted positively with BWYV MAb, 22 with CPCSV MAbs, and 23 samples reacted with both BWYV and CpCSV MAbs. However, sequence analyses showed that no samples were infected with either BWYV or CpCSV. This demonstrates that virus identification based solely on serology can be inaccurate due to cross reactions between specific MAbs and a range of viruses in Polerovirus. Our approach of initially screening large numbers of symptomatic field samples by serology, followed by molecular confirmation of species from serologically-positive samples, has proved to be useful to accurately identify virus species involved in disease outbreaks.

Although results of serological tests confirmed the growing importance and challenge caused by luteovirids in legume crops in the WANA region, there have been many indications that the use of serological techniques 


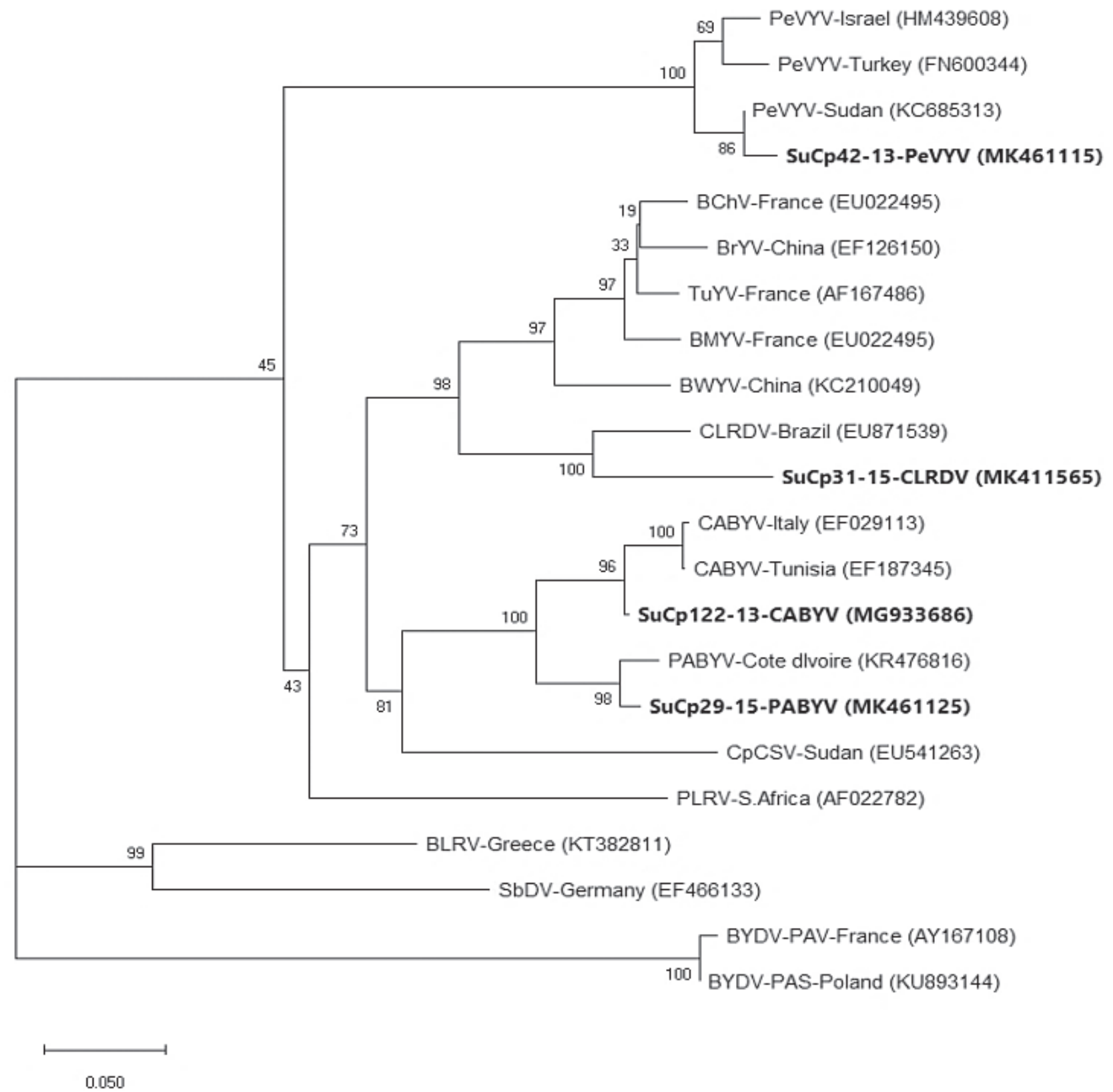

Figure 3. Dendrogram showing the phylogenetic relationships of the predicted partial coat protein amino acid sequences from AS3/ Pol3870F fragment of new detected distinct luteovirid isolates with those of other luteovirids from the database. The scale bar represents 0.050 divergence of the Hasegawa-Kishino-Yano dissimilarity index. Bootstrap analysis was carried out with 1000 replicates of the starting tree. Bootstrap values are shown in each branch. Database accession numbers of the luteovirid sequences and the virus acronyms used are presented in Table 5 .

are not sufficiently reliable for the identification of luteovirid species, because different luteovirids share a number of epitopes (Martin and D'Arcy, 1990; Fortass et al., 1997; Abraham et al., 2006). However, as Makkouk and Kumari (1996) confirmed, TBIA is a helpful method for easy, rapid and cheap detection of plant viruses, especially in the developing countries, and TBIA can be an important tool for virus detection in large scale surveys. The molecular detection method for CABYV, PABYV, PeVYV and CLRDV diagnoses used in this study showed the RT-PCR analysis is very reliable for detection of these four viruses in symptomatic samples. 

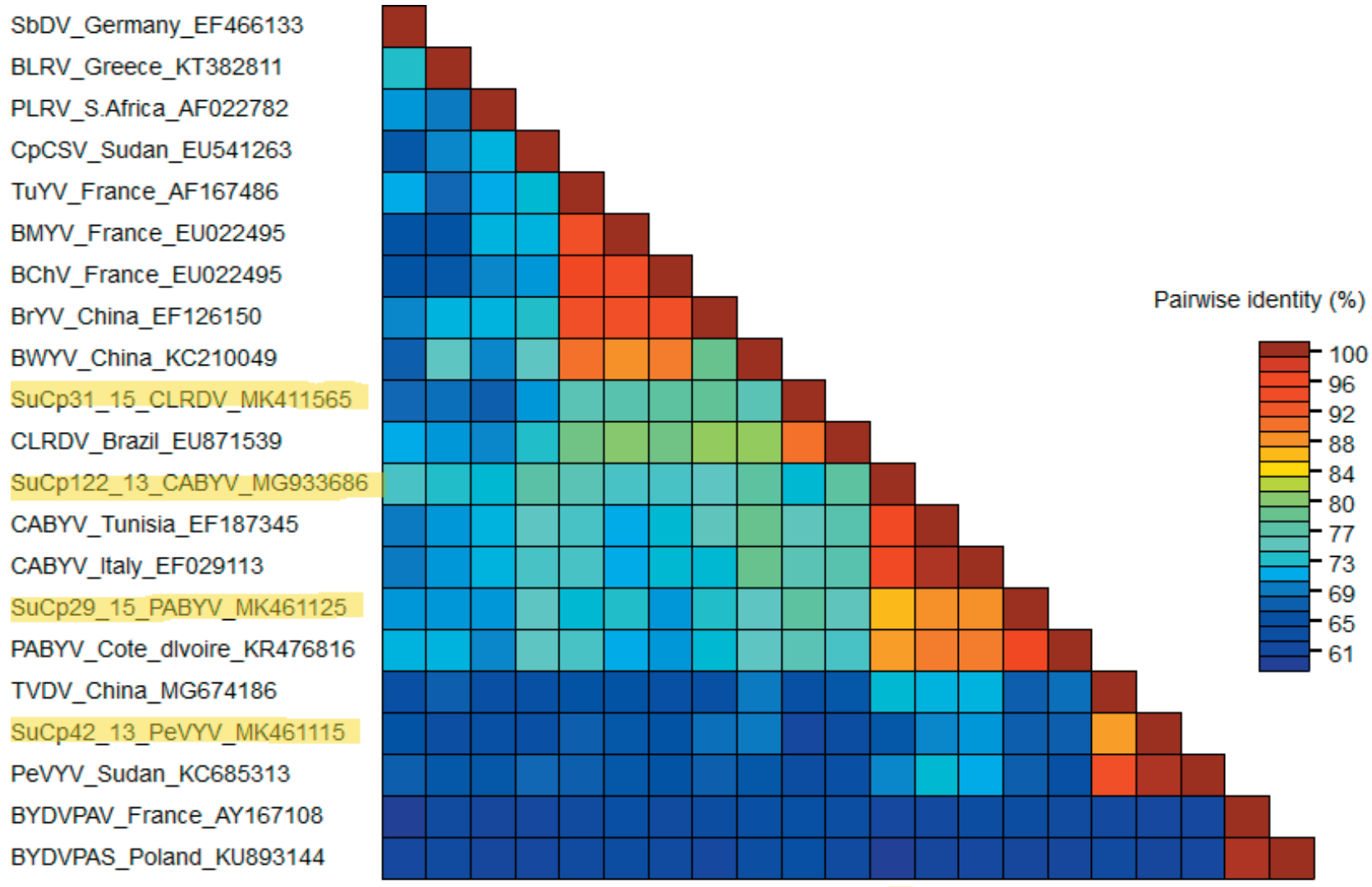

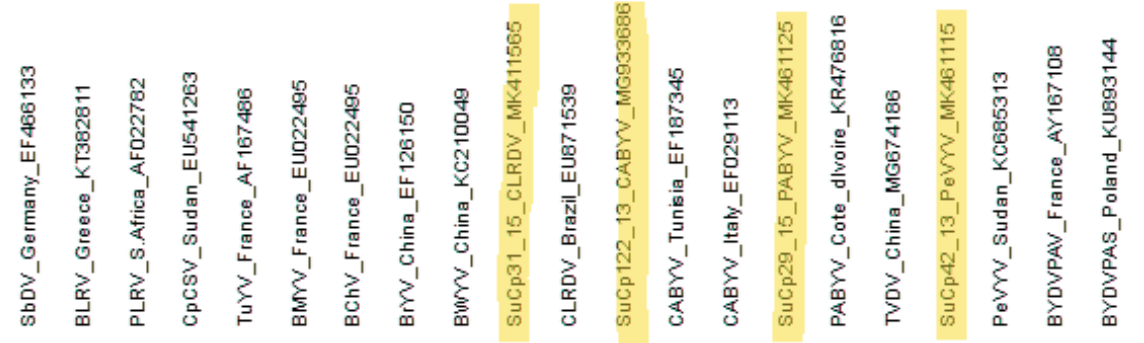

Figure 4. Two dimensional percentage pair wise similarity plot matrix of different selected strains of Luteoviridae generated using the Species Demarcation Tool (http://web.cbio.uct.ac.za/SDT). Each coloured cell represents a percentage similarity between two sequences (one indicated horizontally to the left and the other vertically at the bottom) displayed in the colour key. The luteovirid isolates from Sudan are highlighted, and all accessions details used for this study are listed in Table 5.

Therefore, the MP-PCR method, which can rapidly identify luteovirids, is an important tool for identifying and determining the distribution of luteoviruses that affect cool season legumes. Generally, MP-PCR technology, in addition to sensitivity and specificity, has the added benefits of saving time and costs compared with Uniplex RT-PCR (Deb and Anderson, 2008; Murray Sharman, unpublished data).

The field surveys carried out in the present study indicated that Aphis craccivora is present in most chickpea fields. Aphis craccivora is polyphagous and preferences Fabaceae hosts, but other host plant families include Brassicaceae, Cucurbitaceae, Malvaceae, and Solanaceae. Crops attacked by this aphid include brassicas, cucurbits, beetroot, peanut, cotton, cowpeas and chickpea. In addition, this aphid is the vector of a number of plant viruses including Luteoviridae species. The major crops in Gezira Scheme are cotton, vegetable and chickpeas, and the viruses reported on chickpea in this study also affect cotton and vegetable crops. Further study is therefore needed on behaviour of aphid species in agriculture systems in the Gezira Scheme to use the information for effective management of these viruses. Furthermore, occurrence of these new viruses suggests 
Table 5. Pairwise comparisons of the percentage amino acid sequence similarities for partial CP gene (AS3/Pol3870F fragment) of four distinct luteovirid sequences amplified from four representative samples with that of other luteovirids from the database and to each other.

\begin{tabular}{|c|c|c|c|c|c|}
\hline \multirow[b]{2}{*}{ Virus species (source) } & \multirow{2}{*}{$\begin{array}{c}\text { Accession } \\
\text { Number }\end{array}$} & \multicolumn{4}{|c|}{ Sequenced representative Isolates } \\
\hline & & $\begin{array}{c}\text { SuCp42-13 } \\
\text { (PeVYV) }\end{array}$ & $\begin{array}{c}\text { SuCp29-15 } \\
\text { (PABYV) }\end{array}$ & $\begin{array}{c}\text { SuCp31-15 } \\
\text { (CLRDV) }\end{array}$ & $\begin{array}{c}\text { SuCp122-13 } \\
\text { (CABYV) }\end{array}$ \\
\hline Barley yellow dwarf virus-PAS (Poland) & KU893144 & 43.43 & 45.83 & 42.55 & 50.00 \\
\hline Barley yellow dwarf virus-PAV (France) & AY167108 & 43.43 & 45.83 & 42.55 & 49.36 \\
\hline Bean leafroll virus (Greece) & KT382811 & 52.53 & 58.95 & 58.06 & 64.83 \\
\hline Soybean dwarf virus (Germany) & EF466133 & 57.58 & 66.32 & 60.22 & 65.73 \\
\hline Beet chlorosis virus (France) & EU022495 & 65.06 & 75.31 & 75.00 & 76.98 \\
\hline Beet mild yellowing virus (France) & EU022496 & 62.65 & 74.07 & 75.00 & 77.42 \\
\hline Beet western yellows virus (China) & КC210049 & 64.65 & 80.00 & 78.72 & 75.00 \\
\hline Brassica yellows virus (China) & EF126150 & 61.46 & 76.67 & 79.78 & 80.45 \\
\hline Carrot red leaf virus (Mauritius) & FJ969849 & 57.69 & 59.18 & 51.11 & 61.11 \\
\hline Chickpea chlorotic stunt virus (Syria) & EU541270 & 60.42 & 79.12 & 70.00 & 80.58 \\
\hline Cotton leafroll dwarf virus (Brazil) & EU871539 & 61.62 & 78.95 & 96.17 & 76.97 \\
\hline Cucurbit aphid-borne yellows virus (Italy) & EF029113 & 61.62 & 89.36 & 75.79 & 97.93 \\
\hline Cucurbit aphid-borne yellows virus (Tunisia) & EF187345 & 60.42 & 89.01 & 75.00 & 97.24 \\
\hline Pepo aphid-borne yellows virus (Cote d'Ivoire) & KR476816 & 62.11 & 96.70 & 73.33 & 88.97 \\
\hline Pepper vein yellows virus (Sudan) & КС685313 & 100.00 & 62.50 & 60.00 & 63.16 \\
\hline Potato leafroll virus (South Africa) & AF022782 & 60.61 & 65.62 & 61.70 & 68.21 \\
\hline Tobacco vein distorting virus (China) & MG674186 & 74.95 & 65.62 & 58.95 & 65.97 \\
\hline Turnip yellows virus (France) & AF167486 & 67.47 & 75.31 & 75.00 & 79.84 \\
\hline SuCp42-13-PeVYV (Sudan, this study) & MK461115 & - & 61.70 & 59.57 & 58.89 \\
\hline SuCp29-15-PABYV (Sudan, this study) & MK461125 & & - & $\mathrm{NS}^{*}$ & 60.00 \\
\hline SuCp31-15-CLRDV (Sudan, this study) & MK411565 & & & - & 75.56 \\
\hline SuCp122-13-CABYV (Sudan, this study) & MG933686 & & & & - \\
\hline
\end{tabular}

* NS: No significant similarity found.

the need for further screening of legume crops, including chickpea, for resistance to luteovirids, and for development of new management strategies to incorporate host resistance as an important component for virus disease control.

Despite the limited number of samples analyzed for sequencing, PABYV sequences were amplified from the majority of the luteovirid-positive samples analyzed (14 samples of 24 sequenced samples), followed by PeVYV and CABYV. This suggests that these viruses are widespread in cool-season food legumes grown in the WANA countries, and are more prevalent than the other luteovirids detected so far from the region, such as BLRV and SbDV (Fortass and Bos, 1991; Tadesse et al., 1999; Abraham et al., 2000; Makkouk et al., 2003a). The observed variability within the sequences together with detection in samples from different locations and different luteovirids, suggest that these viruses have been infecting legumes for many years in Sudan but have remained undetected and/or incorrectly identified as one of the other legume luteovirids, possibly due to the lack of appropriate diagnostic methods. In addition, PeVYV has been previously reported infecting hot pepper (Capsicum annuum) in Sudan (Alfaro-Fernándezn et al., 2014). The molecular analysis found that PeVYV chickpea isolate (SuCp42-13, GenBank accession no. MK461115) was almost identical to the Sudanese PeVYV isolated from pepper (GenBank accession no. -KC685313), indicating that both chickpea and pepper isolates are same, or are very similar, but this virus has not been previously recognized in grain legumes due to antibody cross reactions.

Most previous studies have been based on serological tests that are not reliable for the identification of luteovirids to species level. The present study has confirmed the occurrence of CABYV, PABYV, PeVYV and CLRDV in Sudan, using robust molecular techniques. These samples reacted serologically with one or more of antibodies specific to BWYV and CpCSV, suggesting they share a common epitope with these two viruses. 
CABYV was first described in 1992 in France (Lecoq et al., 1992), but was later detected infecting cucurbits in many other countries (Kassem et al., 2013). In addition to cucurbits, CABYV can infect other crop species, including lettuce (Lactuca sativa) and fodder beet (Beta vulgaris), as well as some common weeds (Kassem et al., 2013), which are thought to be virus reservoirs. Recently, CABYV was reported to infect faba bean (Vicia faba L.) in Turkey (Buzkan et al., 2017), and the present study is the first report of CABYV affecting chickpeas. CABYV is transmitted by Aphis gossypii and Myzus persicae (Lecoq et al., 1992), and both these vectors have very broad host ranges. Further disease surveillance is required to determine if CABYV is also present in other grain legume production regions of the world.

Cotton blue disease (CBD) was first described in the Central African Republic in 1949 (Cauquil and Vaissayre, 1971), although no causal agent was characterized at the time. CLRDV has now been shown to cause Cotton blue disease from Brazil (Corrêa et al., 2005). Our detection of CLRDV from Sudan is the first confirmation of this virus from Africa, and this suggests that this virus may have been unnoticed on chickpea in Sudan, where cotton cultivation is widespread. Hence, further research is required to outline the life cycle of this virus on cool season and warm season crops. More recently, CLRDV has been reported on chickpea in Uzbekistan (Kumari et al., 2020).

Sharman et al. (2015) and Mukherjee et al. (2016) indicated that the host range of CLRDV is not well understood, but mainly includes plants in Malvaceae, especially Gossypium spp. While the main vector of CLRDV in cotton is Aphis gossypii (Michelotto and Busoli 2007), this virus is also transmitted by M. persicae and A. craccivora in chickpea (Mukherjee et al., 2016). In Sudan, cotton and chickpea crops are grown in rotation, and they probably share these viruses and their aphid vectors. This may play a role in the epidemiology of these viruses, allowing them to survive between seasons on alternating crops. The study by Reddy and Kumar (2004) on the host range of the chickpea stunt disease associated virus (CpSDaV), most likely synonymous to CLRDV (Naidu et al., 1997; Corrêa et al., 2005), indicated that CLRDV can infect several grain legume species, many of which are commonly cultivated in Sudan, suggesting that CLRDV may have suitable hosts all year around. Mukherjee et al. (2016) studied the genetic similarity between CLRDV and CpSDaV in India, and found that these two viruses are possibly two different strains of the same virus. This information would be helpful for managing these serious diseases, possibly by altering the cropping patterns used by producers.
The present study is the first to report CLRDV and PABYV from crops in Sudan, and is the first report of PeVYV isolated from chickpea in this country. Kumari et al. (2018) made the first report of CABYV in Sudan, and the present report has greatly extended the understanding of the diversity, geographical range and incidence of CABYV in Sudan. In addition, this study is the first reliable molecular characterization for these four Polerovirus species identified from chickpea samples collected in Sudan. Further field investigations and surveys are required to determine more accurately the ongoing impacts and geographical distribution of these newly detected viruses on chickpea and other grain legume crops in the WANA region. Accurate local knowledge of identity of viruses affecting these crops is essential for breeding for disease resistance and effective crop management.

\section{ACKNOWLEDGEMENTS}

This research was supported by the Grains Research and Development Corporation, Australia (Project DAN00202), the Arab Fund for Social and Economic Development (AFSED), Kuwait, and the Department of Agriculture and Fisheries, Queensland, Australia.

\section{LITERATURE CITED}

Abraham A.D., Makkouk K.M., Gorfu D., Lencho A.G., Ali K., ... Lencho A., 2000. Survey of faba bean (Vicia faba L.) virus diseases in Ethiopia. Phytopathologia Mediterranea 39: 277-282.

Abraham A.D., Menzel W., Lesemann D.E., Varrelmann M., Vetten H.J., 2006. Chickpea chlorotic stunt virus: A new Polerovirus infecting cool-season food legumes in Ethiopia. Phytopathology 96: 437-446. https://doi.org/10.1094/phyto-96-0437

Abraham A.D., Varrelmann, M., Vetten H.J., 2008. Molecular evidence for the occurrence of two new luteoviruses in cool season food legumes in Northeast Africa. African Journal of Biotechnology 7: 414420. https://doi.org/10.1007/s00705-009-0374-0

Abraham A.D., Menzel W., Varrelmann M., Vetten H.J., 2009. Molecular, serological and biological variation among Chickpea chlorotic stunt virus isolates from five countries of North Africa and West Asia. Archives of Virology 154: 791-799. https://doi. org/10.1007/s00705-009-0374-0

Alfaro-Fernández A., ElShafie E.E., Ali M.A., El Bashir O.O.A., Córdoba-Sellés M.C., Ambrosio M. F.S., 
2014. First report of Pepper vein yellows virus infecting hot pepper in Sudan. Plant Disease 98: 14461446. https://doi.org/10.1094/PDIS-03-14-0251-PDN

Altschul S.F., Madden T.L., Schäffer A.A., Zhang J., Zhang Z., ... Lipman D.J., 1997. Gapped BLAST and PSIBLAST: a new generation of protein database search programs. Nucleic Acids Research 25: 3389-3402. https://doi.org/10.1093/nar/25.17.3389

Altschul S.F., Wootton J.C., Gertz E.M., Agarwala R., Morgulis A., ... Yu Y.K., 2005. Protein database searches using compositionally adjusted substitution matrices. FEBS Journal 272: 5101-5109. https://doi. org/10.1111/j.1742-4658.2005.04945.x

Asaad N.Y., Kumari S.G., Haj-Kassem A.A., Shalaby A.A., Al-Shaabi S., Malhotra R.S., 2009. Detection and characterization of Chickpea chlorotic stunt virus in Syria. Journal of Phytopathology 157: 756-761. https:// doi.org/10.1111/j.1439-0434.2009.01574.x

Bos L., Hampton R.O., Makkouk K.M., 1988. Viruses and virus diseases of pea, lentil, faba bean and chickpea. In: World crops: cool season food legumes (R.J. Summerfield, ed.), Kluwer Academic Publishers, London, United Kingdom, 591-615.

Buzkan N., Arpaci B.B., Apalak A., 2017. First report of Cucurbit aphid-borne yellows virus in Vicia faba. New Disease Reports 35: 13. https://doi.org/10.5197 /j.2044-0588.2017.035.013

Cauquil J., Vaissayre, M., 1971. La "maladie bleue" du cotonnier en Afrique: transmission de cotonnier à cotonnier par Aphis gossypii Glover (The "blue disease" of cotton in Africa: transmission cotton to cotton by Aphis gossypii Glover). Coton et Fibres Tropicales 26: 463-466.

Corrêa R.L., Silva T.F., Simões-Araújo J.L., Barroso P.A.V., ... Vaslin M.F.S., 2005. Molecular characterization of a virus from the family Luteoviridae associated with cotton blue disease. Archives of Virology 150: 13571367. https://doi.org/10.1007/s00705-004-0475-8

D’Arcy C.J., Torrance L., Martin R.R., 1989. Discrimination among luteoviruses and their strains by monoclonal antibodies and identification of common epitopes. Phytopathology 79: 869-873.

D’Arcy C.J., Domier L.L., 2005. Family Luteoviridae. In: Virus Taxonomy: Classification and Nomenclature of Viruses, Eighth Report of the International Committee on the Taxonomy of Viruses (C.M. Fauquet, M.A. Mayo, J. Maniloff, U. Desselberger, L.A. Ball, ed.), Elsevier Academic Press, San Diego, CA, USA, 891900.

Deb M., Anderson J.M., 2008. Development of a multiplexed PCR detection method for Barley and Cereal yellow dwarf viruses, Wheat spindle streak virus,
Wheat streak mosaic virus and Soil-borne wheat mosaic virus. Journal of Virology Methods 148: 17-24. https://doi.org/10.1016/j.jviromet.2007.10.015

Domier L.L., 2011. Family Luteoviridae. In: Virus Taxonomy: Classification and Nomenclature of Viruses, Ninth Report of the International Committee on Taxonomy of Viruses (A.M.Q. King, M.J. Adams, E.B. Carstens, E.J. Lefkowitz, ed.), Elsevier, Oxford, 1045-1053.

Duffus J.E., Russell G.E., 1975. Serological relationship between Beet western yellows and Beet mild yellowing viruses. Phytopathology 65: 811-815. https://doi. org/10.1094/Phyto-65-811

FAO, 2018. Pulse Quantity Production. Food and Agriculture Organization of the United Nations. Statistical Databases, FAO, Italy. Available online at: http:// www.fao.org/faostat/en/

Fortass M.F., Bos L., 1991. Survey of faba bean (Vicia faba L.) for viruses in Morocco. Netherlands Journal of Plant Pathology 97: 369-380.

Fortass M.F., van der Wilk F., Goldbach R.W., Bos L., van den Heuvel J.F.J.M., 1996. Diversity of viruses infecting faba bean in Morocco and their detection by the polymerase chain reaction. Agronomie 16: 61-68. https://doi.org/10.1051/agro:19960104

Fortass M.F., Wilk F., Heuvel J.F.J.M., Goldbach R.W., 1997. Molecular evidence for the occurrence of Beet western yellows virus on chickpea in Morocco. European Journal of Plant Pathology 103: 481-484. https:// doi.org/10.1023/A:1008687629522

Franz A., Makkouk K.M., Katul L., Vetten H.J., 1996. Monoclonal antibodies for the detection and differentiation of Faba bean necrotic yellows virus isolates. Annals of Applied Biology 128: 255-268. https://doi. org/10.1111/j.1744-7348.1996.tb07321.x

Govier D.A., 1985. Purification and partial characterisation of Beet mild yellowing virus and its serological detection in plants and aphids. Annals of Applied Biology 107: 439-447. https://doi. org/10.1111/j.1744-7348.1985.tb03160.x

Hasegawa M., Kishino H., Yano T.A., 1985. Dating of the human-ape splitting by a molecular clock of mitochondrial DNA. Journal of Molecular Evolution 22: 160-174. https://doi.org/10.1007/bf02101694

Hauser S., Stevens M., Mougel C., Smith H.G. Fritsch C., ... Lemaire O., 2000. Biological, serological, and molecular variability suggest three distinct polerovirus species infecting beet or rape. Phytopathology 90: 460466. https://doi.org/10.1094/PHYTO.2000.90.5.460

Hauser S., Stevens M., Beuve M., Lemaire O., 2002. Biological properties and molecular characterization of Beet chlorosis virus (BChV). Archives of Virology 147: 745-762. https://doi.org/10.1007/s007050200023 
Kassem M. A., Juarez M., Gómez P., Mengual C. M., Sempere R. N., ... Aranda M.A., 2013. Genetic diversity and potential vectors and reservoirs of Cucurbit aphid-borne yellows virus in southeastern Spain. Phytopathology 103: 1188- 1197. https://doi. org/10.1094/PHYTO-11-12-0280-R

Katul L., 1992. Characterization by serology and molecular biology of Bean leaf roll virus and Faba bean necrotic yellows virus. PhD Thesis. University of Göttingen, Göttingen, Germany. 115 pp.

Knierim D., Deng T., Tsai W.S., Green S.K., Kenyon L., 2010. Molecular identification of three distinct Polerovirus species and a recombinant Cucurbit aphid-borne yellows virus strain infecting cucurbit crops in Taiwan. Plant Pathology 59: 991-1002. https://doi.org/10.1111/j.1365-3059.2010.02327.x

Kumar P.L., Kumari S.G., Waliyar F., 2008. Virus diseases of chickpea. In Characterization, Diagnosis and Management of Plant Viruses: Vegetable and Pulse Crops. Vol 3 (G.P. Rao, P.L. Kumar, R.J. Holguin-Pena, ed.), Studium Press LLC, Texas, USA, 213-234.

Kumar S., Stecher G., Li M., Knyaz C., Tamura K., 2018. MEGA X: Molecular evolutionary genetics analysis across computing platforms. Molecular Biology and Evolution 35: 1547-1549. https://doi.org/10.1093/molbev/msy096

Kumari S.G., Makkouk K.M., Attar N., 2006. An improved antiserum for sensitive serologic detection of Chickpea chlorotic dwarf virus. Journal of Phytopathology 154: 129-133. https://doi.org/10.1111/ j.1439-0434.2006.01068.x

Kumari S.G., Makkouk K.M., 2007. Virus diseases of faba bean (Vicia faba L.) in Asia and Africa. Plant Viruses 1: 93-105.

Kumari S.G., Makkouk K., Asaad N., Attar N., Loh M.H., 2007. Chickpea chlorotic stunt virus affecting coolseason food legumes in west Asia and north Africa. Page 157. In: Abstract book of 10th International Plant Virus Epidemiology Symposium, on the theme "Controlling Epidemics of Emerging and Established Plant Virus Diseases - The Way Forward”. 15-19 October 2007, Hyderabad, India. 209 pp.

Kumari S.G., Larsen R., Makkouk K.M., Bashir M., 2009. Virus diseases of lentil and their control. In: The Lentil: Botany, Production and Uses (W. Erskine, F.J. Muehlbauer, A. Sarker, B. Sharma, eds). CABI, UK, 306-325. https://doi. org/10.1079/9781845934873.0000

Kumari S.G., Ziyaev Z., Kemal S., 2017. Viral diseases affecting chickpea crop in Uzbekistan. Phytopathologia Mediterranea 562: 356. https://doi.org/10.14601/ Phytopathol_Mediterr-20879
Kumari S. G., Moukahel A.R., Hamed A.A., Sharman M., 2018. First Report of Cucurbit aphid-borne yellows virus Affecting Chickpea (Cicer arietinum L.) in Sudan. Plant Disease 102: 2048. https://doi. org/10.1094/PDIS-02-18-0347-PDN

Kumari S.G., Sharman M., Moukahel A., Ziyaev Z., Ahmed S., 2020. First report of Cotton leafroll dwarf virus affecting chickpea (Cicer arietinum L.) in Uzbekistan. Plant Disease 104: 2532. https://doi. org/10.1094/PDIS-01-20-0085-PDN

Lecoq H., Bourdin D., Wipf-Scheibel C., Bon M., Lot H., ... Herbach. E., 1992. A new yellowing disease of cucurbits caused by a luteovirus, Cucurbit aphidborne yellows virus. Plant Pathology 41: 749-761. https://doi.org/10.1111/j.1365-3059.1992.tb02559.x

Lemaire O., Herrbach E., Stevens M., Bouchery Y., Smith H.G., 1995. Detection of sugar beet-infecting Beet mild yellowing luteovirus isolates with a specific RNA probe. Phytopathology 85: 1513-1518. https:// doi.org/10.1094/Phyto-85-1513

Makkouk K.M., 2020. Plant pathogens which threaten food security: viruses of chickpea and other cool season legumes in West Asia and North Africa. Food Security 12: 495-502. https://doi.org/10.1007/s12571020-01017-y

Makkouk K.M., Bos L., Azzam O.I., Kumari S., Rizkallah A., 1988. Survey of viruses affecting faba bean in six Arab countries. Arab Journal of Plant Protection: 6: 53-61.

Makkouk K.M., Dafalla G., Hussein M., Kumari S.G., 1995. The natural occurrence of Chickpea chlorotic dwarf geminivirus in chickpea and faba bean in the Sudan. Journal of Phytopathology 143: 465-466. https://doi.org/10.1111/j.1439-0434.1995.tb04555.x

Makkouk K.M., Kumari S.G., 1996. Detection of ten viruses by tissue blot immunoassay (TBIA). Arab Journal of Plant Protection 14: 3-9.

Makkouk K.M., Kumari S.G., Shahraeen N., Fazlali Y., Farzadfar S., ... Mansouri R.A., 2003a. Identification and seasonal variation of viral diseases of chickpea and lentil in Iran. Journal of Plant Diseases and Protection 110: 157-169.

Makkouk K.M., Hamed A.A., Hussein M., Kumari S.G., 2003b. First report of Faba bean necrotic yellows virus (FBNYV) infecting chickpea (Cicer arietinum) and faba bean (Vicia faba) crops in Sudan. Plant Pathology 52: 412. https://doi.org/10.1046/j.13653059.2003.00833.x

Makkouk K.M., Kumari S.G., Hughes J.d'A., Muniyappa V., Kulkarni N.K., 2003c. Other legumes: Faba bean, chickpea, lentil, pigeonpea, mungbean, blackgram, lima bean, horegram, bambara groundnut 
and winged bean. In: Virus and Virus-like Diseases of Major Crops in Developing Countries (G. Loebenstein, G. Thottappilly, ed.), Kluwer Academic Publishers, Dordrecht, The Netherlands, 447-476.

Makkouk K.M., Kumari S.G., 2009. Epidemiology and integrated management of persistently transmitted aphid-borne viruses of legume and cereal crops in West Asia and North Africa. Virus Research 141: 209-218. https://doi.org/10.1016/j.virusres.2008.12.007

Makkouk K.M., Kumari S.G., van Leur J.A.G., Jones, R.A.C., 2014. Control of plant virus diseases in cool-season grain legume crops. Advances in Virus Research 90: 207-253. https://doi.org/10.1016/B9780-12-801246-8.00004-4

Martin R.R., D’Arcy C.J., 1990. Relationship among luteoviruses based on nucleic acid hybridization and serological studies. Intervirology 31:23-30. https://doi. org $/ 10.1159 / 000150130$

McKenzie D.J., McLean M.A., Mukerji S., Green M., 1997. Improved RNA extraction from woody plants for the detection of viral pathogens by reverse transcription-polymerase chain reaction. Plant Disease 81: 222-226. https://doi.org/10.1094/ PDIS.1997.81.2.222

Merga B., Haji J., 2019. Economic importance of chickpea: Production, value, and world trade. Cogent Food \& Agriculture 5: 1615718. https://doi.org/10.1080/233 11932.2019.1615718

Michelotto M.D., Busoli A.C., 2007. Caracterização da transmissão do virus do mosaico-das-nervuras do algodoeiro pelo pulgão Aphis gossypii com relação a ersistencia e ao tempo necessario para inoculação. Bragantia 66: 441-447. https://doi.org/10.1590/ S0006-87052007000300010

Mnari-Hattab M., Gauthier N., Zouba A., 2009. Biological and molecular characterization of the Cucurbit aphid-borne yellows virus affecting cucurbits in Tunisia. Plant Disease 93: 1065-1072. https://doi. org/10.1094/pdis-93-10-1065

Mohamed A.A., Tahir I.S., Elhashimi A.M., 2015. Assessment of genetic variability and yield stability in chickpea (Cicer arietinum L.) cultivars in River Nile State, Sudan. Journal of Plant Breeding and Crop Science 7: 219-225. https://doi.org/10.5897/ JPBCS2015.0523

Mohamed O.E., Ahmed S., Singh M., Ahmed N.E., 2018. Association of crop production practices on the incidence of wilt and root rot diseases of chickpea in the Sudan. Arab Journal of Plant Protection 36: 21-26.

Muhire B.M., Varsani A., Martin D.P., 2014. SDT: A virus classification tool based on pairwise sequence align- ment and identity calculation. PLoS ONE 9: e108277. https://doi.org/10.1371/journal.pone.0108277

Mukherjee A.K., Mukherjee P.K., Kranthi S., 2016. Genetic similarity between Cotton leafroll dwarf virus and Chickpea stunt disease associated virus in India. The Plant Pathology Journal 32: 580-583. https://doi.org/10.5423/ppj.nt.09.2015.0197

Mustafayev E., Kumari S.G., Attar N., Zeynal A., 2011. Viruses infecting chickpea and lentil crops in Azerbaijan. Australasian Plant Pathology 40: 612-620. https://doi.org/10.1007/s13313-011-0094-2

Naidu R.A., Mayo M.A., Reddy S.V., Jolly C.A., Torrance L., 1997. Diversity among the coat proteins of luteoviruses associated with chickpea stunt disease in India. Annals of Applied Biology 130: 37-47. https:// doi.org/10.1111/j.1744-7348.1997.tb05781.x

Nene Y.L., Sheila V.K., Sharma S.B., 1996. A world list of chickpea and pigeonpea pathogens. $5^{\text {th }}$ edition. Patancheru 502324, Andhra Pradesh, India: International Crops Research Institute for the Semi-Arid Tropics (ICRISAT) (Semi-formal publication), $27 \mathrm{pp}$.

Oshima K., Shikata E., 1990. On the screening procedures of ELISA for monoclonal antibodies against three luteoviruses. Annals of the Phytopathological Society of Japan 56: 219-228. https://doi.org/10.3186/ jjphytopath.56.219

Reddy S.V., Kumar P.L., 2004. Transmission and properties of a new luteovirus associated with chickpea stunt disease in India. Current Science 86: 11571161.

Shang Q., Xiang H., Han C., Li D., Yu J., 2009. Distribution and molecular diversity of three cucurbit-infecting poleroviruses in China. Virus Research 145: 341346. https://doi.org/10.1016/j.virusres.2009.07.017

Sharman M., Lapbanjob S., Sebunruang P., Belot J.-L., Galbieri R., ... Suassuna N., 2015. First report of Cotton leafroll dwarf virus in Thailand using a species-specific PCR validated with isolates from Brazil. Australasian Plant Disease Notes 10: 1-4. https://doi. org/10.1007/s13314-015-0174-1

Sharman M., Appiah A., Filardo F., Nancarrow N., Congdon B., ... Wilson C., 2021. Biology and genetic diversity of Phasey bean mild yellows virus, a common virus in legumes in Australia. Archives of Virology 166: 1575-1589. https://doi.org/10.1007/s00705021-05022-0

Smith H.G., Barker I., Brewer G., Stevens M., Hallsworth P.B., 1996. Production and evaluation of monoclonal antibodies for the detection of Beet mild yellowing luteovirus and related strains. European Journal of Plant Pathology 102: 163-169. https://doi. org/10.1007/bf01877103 
Tadesse N., Ali K., Gorfu D., Yusuf A., Abraham A., ... Kumari S.G., 1999. Survey for chickpea and lentil virus diseases in Ethiopia. Phytopathologia Mediterranea 38: 149-158.

Thompson J.D., Gibson T.B., Plewniak F., Jeanmougin F., Higgins D.G., 1997. The CLUSTAL_X windows interface: flexible strategies for multiple sequence alignment aided by quality analysis tool. Nucleic Acids Research 25: 4876-4882. https://doi.org/10.1093/ nar/25.24.4876

Van der Maesen L.J.G., 1987. Cicer L.: Origin, history and taxonomy of Chickpea. In: Chickpea (M.C. Saxena, K.B. Singh, ed.), CAB International, Wallingford, UK., 11-34.

Xiang H., Shang Q., Han C., Li D., Yu J., 2008a. Complete sequence analysis reveals two distinct poleroviruses infecting cucurbits in China. Archives of Virology 153: 1155-1160. https://doi.org/10.1007/s00705-0080083-0

Xiang H., Shang Q., Han C., Li D., Yu J., 2008b. First report on the occurrence of Cucurbit aphid-borne yellows virus on nine cucurbitaceous species in China. Plant Pathology 57: 390. https://doi.org/10.1111/ j.1365-3059.2007.01664.x

Zhang S.B., Zhao Z.B., Zhang D.Y., Liu Y., Zhang S.B., ... Peng J., 2015. First report of Pepper vein yellows virus infecting red pepper in Mainland China. Plant Disease 99: 1190. https://doi.org/10.1094/pdis-01-150025-pdn 